\title{
Azerbaijan's Energy Resources and BTC (Bakü Tbilisi Ceyhan Is the Name Given to the Pipeline Project Being Built for Crude Oil Transfer) Project
}

\author{
Elnur Hasan Mikail1 , Hakan Çora², Ali Nazmi Çora ${ }^{3}$ \\ ${ }^{1}$ Department of Political Sciences and International Relations, Faculty of Economics and Administrative Sciences, Kars Kafkas \\ University, Kars, Turkey \\ ${ }^{2}$ Department of Business, Faculty of Business and Administrative Sciences, Istanbul Okan University, Istanbul, Turkey \\ ${ }^{3}$ Department of Business, Faculty of Business, San Ignacio University, Miami, FL, USA \\ Email: emikail@turansam.org,corahakan@gmail.com, alinazmicora@gmail.com
}

How to cite this paper: Mikail, E. H., Çora, H., \& Çora, A. N. (2020). Azerbaijan's Energy Resources and BTC (Bakü Tbilisi Ceyhan Is the Name Given to the Pipeline Project Being Built for Crude Oil Transfer) Project. Open Journal of Political Science, 10, 163-184.

https://doi.org/10.4236/ojps.2020.102012

Received: October 14, 2019

Accepted: February 25, 2020

Published: February 28, 2020

Copyright $\odot 2020$ by author(s) and Scientific Research Publishing Inc. This work is licensed under the Creative Commons Attribution International License (CC BY 4.0).

http://creativecommons.org/licenses/by/4.0/

(c) (i) Open Access

\begin{abstract}
Azerbaijan is a state that has significant oil and gas resources. After gaining its independence, it attempted to solve its own political and economic problems with the realization of projects related to the exploitation of these resources. The basic policy of the state is the diversification of transport routes to export its own energy resources to the world markets. This article elucidates and places the hydrocarbon-rich Caspian region in the context of the energy needs of energy Turkey and the rest of the region. The importance of transportation routes from the Caspian is highlighted and the potential of Caspian petrochemicals or cooperation in energy field is explored. Furthermore, Turkey's geographic location is close to Middle East and the Caspian Sea basin where 70 percent of the world's energy resources that have been identified to date is present in accordance with the report of Turkish Ministry of Energy and Natural Sources

(https://www.enerii.gov.tr/en-US/Pages/Petroleum). For the transport of Caspian Sea oil and gas reserves the route reaching the Mediterranean through the eastern Turkey is the shortest and the low-cost, convenient and reliable option from a technological and environmental standpoint. On the other hand, transporting such large amounts of oil from narrow and traffic-intensive Turkish Straits by tankers is not a valid way. For these reasons, Turkey has focused her efforts on the realization of the transfer of Caspian oil and natural gas reserves to the Western market over the East-West Energy Corridor. The pipeline projects connecting the Caucasus and Central Asia to
\end{abstract}


Europe are important for the integration of the region into the West. Safe and commercially profitable pipelines will help the region to achieve stability and prosperity. At this stage, the Baku-Tbilisi-Ceyhan Crude Oil Main Export Pipeline (BTC) Project was planned for both Central Asia and Azerbaijan oil. This is most commonly referred to as Baku Ceyhan (BTC). The construction works are currently in progress as of 2005 and will start to pump Azerbaijan's oil through BTC at full capacity starting from the second quarter of 2005 according to the approximate calculations. Within the scope of this project, Azerbaijan has launched a new project for an alternative route to Baku-Supsa and Baku-Novorossisk oil pipelines. Within the scope of this project, European markets, which are new markets for Azerbaijan Petroleum, are opened. Since Russia is against BTC, it is making all kinds of pressure on Azerbaijan side. Lastly, since 1 January 2005, Russia has stopped exporting its natural gas to Azerbaijan. Russia says that the cause of the incident arose from the problems arising in the natural gas lines imported in Turkmenistan. This article will address the strategy and a tactical step that makes Azerbaijan able to achieve the alternative export routes through BTC and its direct and indirect effects on the region.

\section{Keywords}

Energy Resources, BTC Project, Azerbaijan, Russia, USA, China, Turkey

\section{Introduction}

However, the incident was echoed in Baku as a political game of Russia to Azerbaijan within the scope of the BTC project, which is almost to be completed. Around 1 billion dollars' worth of Azerbaijan oil per year will be exported to European markets over Ceyhan, Mediterranean route in the scope of BTC. It is estimated that both Azerbaijan's the oil producer and Georgia as a transit country as well as in Turkey will profit from the project. (http://www.ans.az; compiled from the news topic in the main news bulletin on the independent ANS Television of Azerbaijan ANS TV Main Newsletter dated January 9, 2005).

The legal framework of the BTC Project was completed at the end of 2000. Detailed engineering work was finalized in June 2002. The construction phase, which is the third and last phase, started on 10 September 2002 and is expected to last for 32 months. The groundbreaking ceremony for construction was made on September 18, 2002, with the participation of the Presidents of Turkey, Azerbaijan, Georgia and US Secretary of Energy in the Azerbaijan's Sengaçal region. In addition, in October 2002 between Turkey and Azerbaijan, in December 2002 between Turkey and Georgia BTC Project Environmental and Social Impact Assessment was approved. The first tanker to carry the Caspian oil is expected to be loaded in Ceyhan in the second half of 2005. Regional energy trends played an important role in the determination of the pipeline route. The BTC pipeline 
will not only transport Caspian oil to the Western markets, but also reduce tanker traffic in the Turkish Straits, safeguard navigation, protect the environment and contribute to the security of Istanbul's 15 million population (Abbasli, 2001) (http://www.mfa.gov.tr; 2 Ocak, 2005).

The BTC Project provides a robust and viable option for Europe to diversify energy supply in a regular, safe and cost-effective way. This project is not only economic but also the safest and most strategically sound route in terms of the environment. Thus, Turkey will facilitate the transportation of Caspian oil and natural gas in a safe manner to the world market. Another important project of the East-West Energy Corridor is the Baku-Tbilisi-Erzurum (BTE) Natural Gas Pipeline. The legal framework of this project which will transfer the Azeri gas over Georgia to Turkey is completed and the delivery of Azeri gas is expected to begin in 2006. This also constitutes the first step of the Pipeline Project of the Caspian Pass, which will transport Turkmen gas to Europe. The transportation of Caspian oil and natural gas resources with more than one pipeline will allow European countries to diversify and secure their energy supply. South European Gas Ring project within the framework of the interconnection of natural gas pipelines in Turkey and Greece, will form an important part of the future of Europe's efforts to diversify energy sources. The Intergovernmental Agreement between Turkey and Greece on this subject was signed in February 2003; Natural Gas Sales and Purchase Agreement between DEPA and Botas were signed in December 2003 thus providing Turkey's energy network to that of EU. Turkey is an important energy partner and energy policy of Turkey is consistent with the EU's energy security policy. Energy strategy, constitutes an important area of cooperation between Turkey and the EU.

(http://www.mfa.gov.tr/MFA_tr/DisPolitika/GenelGorunum/Genel+Gorunum.h tm; 20 Kasim, 2004).

\section{The Proposal to Azerbaijan for Procurement of Goods in Exchange of Energy}

Turkish Minister of State Tüzmen met with Azerbaijani President Ilham Aliyev as part of his contacts in Baku. Minister of State Kürşad Tüzmen proposed to the President of Azerbaijan Ilham Aliyev, whom he met in Baku, for the export of goods and services against energy. Saying that this proposal could provide important inputs for both sides, Tüzmen added that if the proposal was accepted by Azerbaijan, it would contribute $\$ 1$ billion to the trade volume (Aktukun, 1995).

Saying that Azerbaijan does not want to base its economy on oil completely, Tüzmen pointed out that they want to shift from the energy sector to the service sector except petroleum products (Aliyarov \& Mahmudov, 1989).

Emphasizing that Turkey wants to do a lot of work in various fields in Azerbaijan and this country still has very pristine areas, Tüzmen underlined that Turkey already has numerous goods and services to provide to this country.

Saying that the banking system is a deficiency in Azerbaijan and the banking system is seen to be developed in order to increase trade very well, Tüzmen un- 
derlined that there are many successful examples of trade in exchange of goods realized with many countries. But still many Azerbaijani firms turn to private sources for finance. Some Azerbaijani banks have begun lending to the private sector, including construction, telecoms, food processing, and packaging. Western businesses use a handful of local banks for their local business dealings. Since the beginning of 2016, the Central Bank of Azerbaijan has terminated the licenses of 11 banks. The banking sector has consolidated significantly following the devaluations in 2015.

(https://www.privacyshield.gov/article?id=Azerbaijan-Banking-Systems).

Also, Mr. Kursat Tuzmen stated that even though exchange of goods is normally made against payment of money, he emphasized that between the countries such as Turkey and Azerbaijan sharing a common language, religion and history union a number of mechanisms can easily be put into practice.

(http://www.525ci.com; 19-11-2004).

\section{Current Political Situation and Local Elections in Azerbaijan}

Local elections in Azerbaijan to determine the municipal administration and municipal councilors began at 06:00. Azerbaijani President Ilham Aliyev and his wife Mehriban Aliyeva voted in the T. K. Insmailov High School, which was designated as the 6th district in the district of Sebail in Baku. Aliyev answered the questions of journalists after voting and indicated that the voting process was following the normal course and stated that the democratization process was continuing (Makas, 1990).

"The opposition in the previous elections, has shot himself, still has not recovered" said Aliyev. He said that the opposition must come from national forces. A total of 21 thousand 622 people will be elected for the administration of 2 thousand 732 municipalities in the election which was boycotted by the leading opposition parties-Musavat, the People's Front (AHCP) and the Democrats (ADP) (Ulku, 1996).

According to the Central Election Commission (CEC), more than 38,000 candidates a total of 31 political parties are participating in the elections. In the morning of the voting process, there was no intense participation in the polling stations, while the officials of the CEC stated that participation was expected to increase especially in the noon time and the second half of the day.

(http://www.xeber.net; 17-12-2004).

As a result of 2018 general elections, giving to exit polls outcomes, 80 to 85 percent of voters have voted for Aliyev, which means that Ilham Aliyev has won the appointment. The balloting command said attendance was about 75 percent and there were no criticisms concerning irregularities. He and his backers reject accusations of voter fraud and state dissension has not been blocked. Aliyev was initially put into power in October 2003, two months before the death of his father, Heydar Aliyev, who governed for 10 years. He strengthened his place with 
two referendums, one in 2009 that scrapped a two-term presidential limit and another in 2016 that prolonged the presidential term to from 5 years to 7 years. Aliyev brought onward the date of the vote to April 11 from Oct. 17, a move his associates said was required to circumvent presidential and parliamentary elections conflicting in 2025. Seven candidates ran, but critics doubted if they were genuine rivals. Monitors, including the Organization for Cooperation and Security in Europe, were observing the vote. The OSCE monitored and presented their observations at a news conference. Aliyev has tried to strike a balance between Azerbaijan's former Soviet master Russia and the West, notably on energy policy. He has profited from a boom fueled by oil exports, but a collapse in global crude prices in the last three years has damaged the Azeri currency and contracted the economy (Ulku, 1996).

(https://www.reuters.com/article/us-azerbaijan-election/azerbaijan-votes-in-pres idential-election-with-aliyev-set-for-fourth-term-idUSKBN1HH3CJ).

\section{Turkey-Azerbaijan Seed Production and Research Establishment Project}

The rich agricultural areas in Azerbaijan and the wide variety of climatic zones make it possible to grow a wide variety of crops. Agriculture is the second important branch for development and investment in Azerbaijan's economy. Azerbaijan has the 9 climatic regions of the total 13 climatic regions in the world. This range extends from the subtropical climate to the tundra climate. This makes it possible to obtain a wide range of quality and high value products. But, like other new republics, agriculture is still experiencing difficulties in the transition to the new market economy (Aliyarov \& Mahmudov, 1989).

Azerbaijan has a cultivated area of approximately 6.5 million ha, most of which can be irrigated with canals and pipes longer than 40,000 km. According to the statistics of 1998, the number of the population living in rural areas is 3 600,000 . Of this population, 871,600 are engaged in agricultural activities with official employment. Private ownership of the lands ended in 1920, when the Soviets occupied Azerbaijan. After this date, the agricultural lands began to be managed by agricultural cooperatives based on state ownership, called kolkhoz (collective enterprises) and sovhoz (state enterprises). In this period, the Soviet leaders dictated where the products were to be produced and where they would be sent after harvest. It was later discovered that Azerbaijan had an extraordinary potential for agriculture and especially fruit and vegetable growing. The Lankaran region is particularly suitable for the production of cabbage, tomatoes and peppers. This region is located on the southern border of the country near Iran. When the region was very fertile in the past, it was called the "Garden of the Whole Union". In addition, in Guba, Khachmaz and Masalli regions vegetables had a great importance. In total, Azerbaijan was sending 500,000 - 600,000 tons of vegetables to the Union Fund (Aras, 1998).

The cotton industry is also of great importance for Azerbaijan. In the 1970s 
and 1980s, about one million tons of cotton were produced each year. However, due to the decline in cotton prices in world markets, today's production has decreased considerably. The production of grain in Azerbaijan has increased substantially in the Soviet period and reached up to one million tons in the 1970s and 1980s. In addition, the amount of product obtained from the unit area increased more than three times between 1913 and 1970. The Soviet administration has preferred to focus on the wine industry rather than to further increase the grain production in Azerbaijan. One of the agricultural products cut from production in Azerbaijan is rice. Rice was cultivated traditionally in Azerbaijan and for many years in some southern regions (Masalli, Lankaran, Sheki) and at the foot of the Gagavuz mountains in the north. The Soviet leaders said that in the other republics of the USSR too much rice was produced and for this reason production of rice was stopped with a declaration stating that there was no need for rice production in Azerbaijan (Allahverdiyev \& Goycayli, 1996).

In the 1970s, the Communist Party and the Council of Ministers initiated initiatives to develop Azerbaijani agriculture in the direction of grape production. Most of the existing capital is separated for producing and developing of railroads and irrigation pipes and an area of 70,000 - 80,000 hectares of land was reserved for the production of wine grapes. For this purpose, the target was to produce 3 million tons of grapes annually from 1990 onwards. In 1982, annual production amount was increased to 2.1 million tons by increasing the production level (Bunyadov, 1989).

In the light of the aforementioned policies in the Soviet regime, three agricultural production branches were devised by the regime in Azerbaijan:

- Cotton production;

- Wine production;

- Vegetable production.

Very few of these products were kept in Azerbaijan. For example, the cotton produced was sent to Russia and the Russians processed them and produced dresses. Of course, the big profits from this work were also for the Russians. Moscow has always tried to keep Azerbaijan within its structure by making it dependent. Every year, Azerbaijan received 35,000 - 40,000 tons of meat and meat products from the Union Fund with an average of 1,200,000 tons of milk and milk products. Because the Azerbaijani animal production was not allowed by the Soviet administration. With the excuse of this so-called planned economy, Moscow deprived Azerbaijanis of the right to raise animals. As a result, Azerbaijanis consumed less meat and milk products than other Soviet Republics. For example, while the annual meat consumption per capita of the Soviet Union was $65 \mathrm{~kg}$, this rate was around $37 \mathrm{~kg}$ in Azerbaijan.

After the independence of Azerbaijan, the parliament enacted a law in 1996 that facilitated the privatization of state property. According to this, agricultural lands were divided into private properties. Within the Commonwealth of Independent States, Azerbaijan was the only country to implement this system. In 
Kazakhstan, Uzbekistan and other republics, land is provided for temporary use by rent or leasing. The tractor and other agricultural equipment were transferred to farmer groups on a property sharing basis. For example, a tractor is provided to serve 10 farmers. The farmer who cannot reach the tractor can use the tractor by agreement with others. However, due to the fact that the machines are no longer well-worn and maintenance-free, their use and efficiency are limited. Since the Ministry of Agriculture of Azerbaijan did not have sufficient resources to buy machinery, almost all of the state-owned animals (99.8\% bovine, 98\% sheep) were distributed to the private sector. The remaining animals are used by the government for aquaculture purposes. According to the data of the Ministry of Agriculture of Azerbaijan, more than one million people have owned agricultural land and the number of farms has reached 30,000. New type farms are formed in collective forms of former Soviet type (kolkhoz) (Abbasli, 2001).

The Ministry of Agriculture of Azerbaijan is planning to give its internal structure functionality under a new state policy for agriculture. These new reforms within the Ministry have been initiated in the light of recommendations from institutions such as the World Bank, the Islamic Development Bank and the EBRD, and other international financial institutions. Products reduced during the Soviet regime in the country are in the stage of gaining production again. Azerbaijan currently supplies its brass from Iran, Brazil and China. However, rice cultivation started again in the country and in 1999, 3.629 hectares of rice were produced in 2000 in 4.437 hectares. It is hoped that the country will become a self-sufficient country in terms of rice production. After the collapse of the Soviet regime, Azerbaijan turned to more grain production. Currently, all produce 1.5 tons of grain per year for their own needs, but the annual need is around 2.5 tons. In order to increase grain production, a trend towards the conversion of wine vineyards to wheat fields is observed (Gumilev, 1990).

Another product re-production of which is considered is sugar beet. Azerbaijan produced significant amounts of sugar beet before the Soviet regime. However, when Ukraine started to produce this product and started to meet the needs of the USSR, there was no need to produce beets in Azerbaijan. After the independence, in Nakhichevan, Beylagan, Sabirabad, Imishli and Salyan sugar beet began to be reproduced in the region. Today, Azerbaijan produces about $50,000-60,000$ tons of beets annually. However, there are no factories in the country to process sugar beet. Therefore, the beet produced is sent from the border city Bilasuvar to the Ardabil city of Iran. Iran processed the beet and sent it back to Azerbaijan as processed product. This system makes sugar too expensive for Azeri consumers. Therefore, there is a need for the establishment of a sugar beet factory in the country. One of the most profitable trends in the country after the change of regime is cattle breeding. There are a lot of meat and dairy products in the country compared to the past. Almost all of this production is provided by private farms. After the privatization in 1996, cattle breeding increased and farmers started to make money from this sector. In addition, the 
quality of dairy products in the country has also been improved. Currently, Azerbaijani companies produce 15 kinds of dairy products (yogurt, cheddar, white cheese, milk, etc.). The fact that most of the factories are not privatized is one of the biggest bottlenecks in agricultural development. Producers are looking for people to buy all they produce. Some of the products can be offered to the market while they are still fresh. However, the product is wasted and the profit margin decreases since there are no facilities to deliver the remaining fresh products to a factory before they are spoiled (Hartill, 1990).

At the moment, only a few factories are customized and functioning. The factories in Guba and Saatli produce various jams and marmalades in small packages. Another factory in Lankaran produces tomato paste. These three new factories export their products to countries such as Japan, Russia, Belgium and Switzerland. Furthermore, there is a need for the privatization of tea processing factories. While the tea production of Azerbaijan was around 34,000 tons in the 1970s, this amount has decreased over the past time and last year it was only 1 900 tons. This is partly due to the lack of a tea processing factory in the country. However, recently tea factories in Baku were bought by Turkish companies and farmers started to produce tea again. The Azeri tea processed in these factories is mixed with Turkish and Indian tea and offered for sale. The Nagorno-Karabakh war in the past caused great problems in Azerbaijan. Today, 20\% of Azerbaijan's land is occupied by Armenians. Most of these lands are fertile agricultural areas. For example, in the region of Fuzuli 100,000 tons of grapes were produced annually. The city of Zangilan had three grape processing plants and 3000 hectares of vineyards. Aghdam is famous for its cotton and Gubadli is famous for their animal husbandry. When Azerbaijanis were forced to leave this area, they had left about 145,000 cattle in the region (Ismayilov, 1992).

For most growers and producers in the country, the biggest problem is the lack of cash flow. Credit union systems where farmers will borrow money are not yet available. Ministry of Agriculture aims to establish credit unions in every region. However, obstruction or inadequacy in agricultural input purchases can be overcome. When Azerbaijan exceeds the above-mentioned problems, there seems to be a bright future for agriculture. Because the climate and soil conditions of Azerbaijan make it possible to grow the first quality product. After the current transition period, an increase in production efficiency will be inevitable. As mentioned, one of the problems of Azerbaijan in the agricultural field is the insufficiency of grain production. The grain production, which was 1.5 million tons in 2000, is expected to increase to 1.7 million tons in 2001. However, this increase is far from meeting the needs of 2.5 million tons. In the seed institutes of the Ministry of Agriculture, activities for testing and production of new seed varieties continue. The most important reason for the fact that the production of the country does not reach the desired level is the failure to reach the desired level of yield in most seed varieties. The main source of this is that the mechanization tools are quite inadequate and old throughout the country, and the production inputs (seed, drug etc.) are forced to be sown without sufficient supply. 
In the study conducted throughout the country, it was observed that the same seed type yielded 4 tons/ha in some regions and this ratio was around 1.5 ton/ha in some regions (Asanishvili, 2003).

In the light of these investigations, the main objective of the project was to provide the necessary technical assistance for the establishment of the facility, which is formerly called the City of Grain Seed Plant, which is formerly called the City of 28 May State Provincial Directorate of Cereal Seeding, operating in the Khachmaz Region, $160 \mathrm{~km}$ north of the Ministry of Agriculture of Azerbaijan. In this way, it is aimed to enable concrete steps to be taken to eliminate the shortage of the grain production still in the country. In addition, enabling the effective promotion of Turkish agricultural technology in Azerbaijan was determined as another objective of the project. In 1996, TIKA sent a total of 32 tons of grain seed to the said enterprise and allowed us to test some of our domestic seeds. As a result of these experiments, it is observed that Dağdaş and Gönen seeds of our country are well adapted to the local conditions. In addition to the project's short-term targets, the Turkish agricultural machinery manufacturing industry will gain an important place in the empty agricultural machinery market in Azerbaijan in the long term. In Azerbaijan, where there is no agricultural lending system, initiatives for this purpose are carried out by Azerbaijani authorities and international organizations. In case of formation of a possible lending system Turkey, as the closest to the said market, is inevitable to have a significant share in this market. Therefore, technology transfer initiatives in this direction need to be accelerated by the cooperation of the state-private sector (Makas, 1990).

The studies related to the project were started with a study tour to Azerbaijan of a delegation formed under the chairmanship of Agricultural Projects Coordinator of our Directorate, Assoc. Prof. Dr. H. Güçlü Yavuzcan in the beginning of March 2001. During this trip, the State City Drilling Plant (28 Mai Devlet Kent Teserrufatı Tahıl Tohumculuk) in Haçmaz was examined together with the Azeri authorities and necessary feasibility reports were prepared. The company has 700 ha area and currently produces grain and legumes. It has been determined that agricultural mechanization tools in the enterprise are quite inadequate and the majority of them have completed their economic life. It is possible to say that this shortage widespread throughout Azerbaijan. Because the lack of a lending system for farmers across the country makes it impossible to renew the existing machines completed their economic life. Furthermore, the fact that unions or rings cannot be established for the use of common machinery also prevents farmers from acting jointly combining their capitals. Considering the fact that the 25-year-old combine harvester present in the establishment works with a $30 \%$ $40 \%$ loss, it is seen why the production which is already decreased due to lack of input, decreases to a very low level. For this reason, it is found necessary to buy a new combine harvester. It has been determined that the two seed cleaning and grading machines in the enterprise are quite old and cannot perform cleaning and separating functions properly, so it is decided to buy two new cleaning and 
grading machines in place of the existing ones completed their economic lives.

The soil is of clay soil, heavy and poor in drainage. In the region where there is a lot of precipitation, the soil gets heavier and therefore, there is a need for larger powerful tractors in field farming. For this reason, it has been adopted that the tractor to be purchased by TIKA is $110 \mathrm{BG}$. It was determined that almost all of the tractors in the plant were used in field works but their operating costs and maintenance-repair costs reached to quite high prices. It was found that the plant was also weak in terms of tillage, sowing and maintenance machines. Instead of existing plows completed their economical lives, a four-body disc and a four-body ear plow are considered suitable. It is foreseen that disc harrow will be more suitable for these conditions, since the soil of the plant is heavy clay and is likely to be further aggravated by early spring precipitation.

It was determined that the flakes had a need for disc harrows, sowing and spraying machines. The results of the examinations were discussed in detail with the competencies of the Ministry of Agriculture of Azerbaijan, and a consensus was reached on the modernization of the plant/enterprise under a new name with the technical contribution of TIKA. The protocol, which regulates the foundation principles of the company under the new name has been prepared by the delegations and was finalized by the Minister of Agriculture of Azerbaijan and President of TIKA on 26-04-2001 and entered into force. With this protocol, TICA has the right to audit in coordination with Azerbaijan Ministry of Agriculture. In addition, it was also emphasized with the prepared protocol that the project provided a real cooperation environment. In addition to the assistance of TIKA, the Ministry of Agriculture of Azerbaijan has taken over the revision of the enterprise building for the modernization of the enterprise, the provision of the necessary environment for the farmer training center and the construction of an enclosed hangar for the machines to be provided. In addition, after the opening of the modernization process, it is possible to be managed by an upper executive board which will be formed by the joint participation of the two parties.

Following the completion of the infrastructure works, it has been decided that the agricultural machinery mentioned below will be provided by TIKA and sent to the plant.

1) Combine Harvester;

2) 110 BG Tractor;

3) 20 Row Combine Planter;

4) Four-body Eared Plow;

5) Four-body Disc Plow;

6) 28 Disc Suspended Disc Harrow;

7) Double Disc Centrifugal Fertilizer Spreader;

8) Finger Type Grass Cutter;

9) $8 \mathrm{~m}$. Spiral Drive;

10) 600-liter Field Sprayer;

11) 2 tons Cleaning and Grading Machine;

12) 2 tons Diesel Engine Seed Selector. 
Because of the fact that combine harvester and $110 \mathrm{hp}$ tractor was not produced in our country, these machines were supplied from outside and were delivered to the plant in May 2001 (Ulku, 2000).

The other machines were obtained from the domestic market via auctions. The utmost importance was given to the quality and quality of these machines and the technical specifications were prepared by taking this issue into consideration. Machines supplied from our country were delivered to the company in June 2001. Modernized plant was opened under the name of "Azerbaijan-Turkey Seed Production and Research Farm" in July 6, 2001 by the Minister of State and Agriculture of Azerbaijan Aliyev Irşat. After the company was put into service, the upper executive committee of the company was established and started its duty. Accordingly, the executive committee was formed by TIKKA Agriculture Projects Coordinator Assoc. Dr. H. Güçlü YAVUZCAN, TIKKA Azerbaijan Program Coordinator Fikret ÖZER, President of Azerbaijan Agricultural Science Center Esat MUSAYEV, Agricultural Science Center Branch Director Salman SALMANOV and Regional Center Manager of Guba Ilham QUBANOV. In its first meeting, the executive committee appointed the managers of the business administration, finalized the order to be submitted to the Azerbaijani Judicial Court for the establishment of the enterprise, discussed the next plan of operation and determined the production pattern in the autumn of 2001 (Aktukun, 1995).

As a result of the technical assistance to the plant, the average grain yield is expected to be between 3.5 and 4 tons in the coming year. In addition, taking into consideration that Dağdaş and Gonen type of seed still in use in the plant has been used for a considerably long time, it is decided to replace it with a new selection and for this purpose 5 tons Dağdaş and 5 tons Gonen seeds were sent to the region from Turkey within the framework of the technical assistance to the plant. Within the scope of the project, the Ministry of Agriculture and Rural Affairs has cooperated with the Directorate of Agricultural Instruments and Machinery Testing Center and the Directorate of Agricultural Production Management, Personnel and Machine Training Center. In the next phase of the project, it is planned to establish a farmer training center in cooperation with TIKA and the Ministry of Agriculture of Azerbaijan and to transfer the developments in agricultural production, agricultural technologies and domestic technologies to Azerbaijani farmers. In addition, the Azerbaijani YAY-CEP cassettes prepared by TIKA are planned to be used at this training center.

(http://www.tika.gov.tr/proje.asp?id=13\&Ulke=2\&Konu=Azerbaycan\%20-\%20Türk iye\%20Tohum\%20Üretim\%20veAraștırmas1\%20İșletmesi\%20Projesi; 18 November, 2004).

\section{Connecting the Sciences Academy of Azerbaijan to the Internet}

With this project it is aimed to provide a constructive and significant foundation for the technical and scientific cooperation as a cornerstone of the mutual coop- 
eration between Turkey and Azerbaijan for the sake of the stability of the relations between the both countries, to contribute to development and to ensure continuity of the existing scientific and technical cooperation between the Azerbaijan Academy of Sciences and the Scientific and Technical Research Council of Turkey (TUBITAK), which is significant in the present day, where the scientific information is rapidly developed and disseminated and scientific research is international, to support this bilateral cooperation in the scientific and technical fields to be compatible with the new political, economic and social environment related to the economic reforms in Azerbaijan and to the integration process in various regions of the world (Aliyarov \& Mahmudov, 1989).

In addition to the fact that the scientific calculation capacity of the Azerbaijan Academy of Sciences has been supported to a certain extent, the potential of scientific and technical publication of the Academy will be greatly increased by using English and especially Turkish alphabet. With this project, Azerbaijan was the first Turkish Republic to connect to the Internet (Allahverdiyev \& Goycayli, 1996; Ismayilov, 1992).

\section{TRT-1 Translations in Azerbaijan}

In accordance with the protocol signed in 1995, rights to broadcast TRT 1 in Azerbaijan were secured. Accordingly, USD 1 million has been paid to Azerbaijan side each year in return for regular broadcasting. Our payments have not been regular since 1997 . We did not have any control over the quality of the broadcast due to unpaid payments. There have always been complaints and reports about the poor quality of the broadcast. The protocol ended on 31 December 2000. All of our debt was paid in mid-2002. The Azerbaijani side demanded that a new protocol be made by TIKA by claiming that they have continued TRT broadcasts since the beginning of 2001 and they want to continue the payment.

\section{Contracting Relations with Azerbaijan}

The amount of projects undertaken by Turkish contracting companies in Azerbaijan has reached 1.3 billion dollars. Within the framework of the Credit Relations in Bilateral Trade, Eximbank has extended a total of USD 250 million credit to Azerbaijan, to cover USD 100 million in exports and USD 150 million in project loans. In addition, a loan of 10 million dollars was granted to the Government of Azerbaijan. A total of $\$ 20$ million credit was extended to Nakhichevan Autonomous Republic. There are about 700 Turkish companies operating in sectors such as oil, communication, banking, education, media, construction materials, food, textile, automotive, iron and steel in Azerbaijan. The total amount of direct investment realized is around USD 1.3 billion $(\mathrm{Gu}$ milev, 1990).

There are 5 Turkish banks operating in Azerbaijan. Azerbaijan's economy, which has been observed to be following a very slow transition process in the transition to free market economy, is largely dependent on oil exports. There- 
fore, Azerbaijan is negatively affected by the decline in oil prices. Unless the necessary reforms are made for the transition to the free market economy, it is obvious that the dependence on oil exports will continue in the coming years. The most important factor in increasing oil exports is the construction of alternative pipelines for transportation. Cooperation with Azerbaijan on the exploration, extraction and transportation of natural gas and oil is continuing. Turkey will play an important role in the transportation of oil, which is the most important natural resource of Azerbaijan, to the world markets. The Business Council, established under DEIK, continues its activities. The cooperation between Azerbaijan and the BSEC and ECO is ongoing (Aras, 1998).

\section{Economic Structure and Basic Economic Indicators}

Privatization works are carried out by the State Property Committee established in 1992 under the presidency. The legal basis of these works is the Law of the Privatization of State Property composed of 27 articles, issued in January 1993 (EIU Azerbaijan Country Report July 2000).

Those who can participate in privatization as buyers are; employees of the facility to be privatized, citizens of the country, non-state legal persons not owning state enterprises or firms, legal entities more than the $25 \%$ of the capital of which does not belong to the state, foreign private and legal entities. Institutions and sectors that cannot be privatized are; oil, natural gas, artistic spaces and mines (http://www.foreigntrade.gov.tr/DUNYA/RAPOR/baku/azerbay.htm; 2 Nisan, 200).

In accordance with the decree of the President dated 8 February 1997, 7.183803 of 8 million State Privatization Shares (Check) issued abroad and brought in the country were distributed to citizens of the Republic of Azerbaijan free of charge. Citizens of the Republic of Azerbaijan and foreigners can participate in privatization with these checks. Facilities and establishments to be privatized are divided into 3 groups according to the privatization program such as small, medium and large. $15 \%$ of the shares of the small enterprises are given to their employees free of charge and $85 \%$ is sold with auction. Medium and large enterprises are first converted into an incorporated company status and then privatized and of these companies; at least $50 \%$ of the shares are privatized by check auctions, $15 \%$ of the shares are sold to the employees in return for checks, $10 \%$ are by open auction and the remaining $25 \%$ is transferred by the state to the closed investment fund. The first Privatization Program covers the years 1995-1998, the Second Privatization Program was approved by the President on 10.08.2000. The second program uses the experience gained from the privatization of small enterprises in the course of the first privatization and it is seen that the second privatization attempts to eliminate the problems that will arise in the privatization of medium and large-scale institutions based on former experience. A total of $\$ 8.5$ million was generated from privatization in 2000 and

a total of \$109 million of revenue from 1996-2000 September (EIU Azerbaijan Country Report April 2000). 
Economic recovery was supported by an extremely high level of direct foreign capital investment (FDI) in the oil sector. In 1999, capital investment decreased by $3 \%$ due to lower foreign investment in oil fields, the closure of two exploration consortiums and the end of the first business of Azerbaijan International Operating Company (AIOC). In the first quarter of 2000, capital investment increased again, but this increase was not significant and realized at the level of $2.4 \%$ annually amounting to 911 billion manats (US $\$ 208$ million, $21.7 \%$ of GDP). The pace of investment growth is lower in the first quarter of 1999 compared to former level of 9\%. Foreign investment in the form of FDI and debt internal flows fell $28 \%$ in the first quarter and amounted to 419.9 billion Manats (US \$95.4 million; 10\% of GDP). State enterprises met the 318.4 billion Manats (7.6\% of GDP) of investment and domestic private investors met 172.7 billion Manats (4.1\% of GDP) (TÜSİAB Publishers).

In 2000, the share of investment in the oil and gas sectors declined substantially annually. Other key buyers of the investment were industrial semi-processing enterprises and realized $2.8 \%$ of GDP in the same period, showing a significant increase. In 2000, a total investment of $\$ 1052$ million was made. The amount of foreign capital is $\$ 536.4$ million and corresponds to $51 \%$ of the total investments. There was an inflow of $\$ 5.2$ billion of foreign capital to Azerbaijan between 1994 and 2000, of which $\$ 3.4$ billion belonged to oil and $\$ 1.8$ billion to non-oil sectors. 4.682.100 hectares of the territory of the country are suitable for arable lands and forests. This area includes 1,735,500 hectares of cultivated areas, 1,038,200 hectares of forest land, 2,622,400 hectares of meadows and pastures, 250,000 hectares of perennial cultivation areas. Azerbaijan has very favorable natural conditions for the production of foodstuffs necessary for the nutrition of the people. However, although climate conditions and natural environment are extremely convenient; due to lack of machinery-equipment, lack of quality seeds, fertilizers and pesticides and lack of agricultural loans due to legal deficiencies in banking legislation, the country potential cannot be realized adequately. In agriculture, private property-based production structure is started. Within the framework of the privatization program, it was decided to privatize 11,039 of 1119 kolkhoz and 559 of 820 sovhoz. 94.9\% of the government property planned for privatization was given to the public (EIU Azerbaijan Country Report 1st Quarter 2000).

The statistics show the world's leading cotton-producing countries in crop year 2018/2019. In that year, cotton production in India amounted to around 5.77 million metric tons.

(https://www.statista.com/statistics/263055/cotton-production-worldwide-by-to p-countries/)

Although the agricultural sector generally experienced an improvement, especially cotton production decreased rapidly. Grape and tea production is also decreasing. Fishing and aquatic products have a special place in the rich streams and along the Caspian Sea coast, which is 800 kilometers long. In the Aras-Kura rivers and especially in the Caspian Sea delta of the Kura River, the fisheries and 
aquaculture industry is very developed. The fish of the sturgeon hunted in the Caspian Sea is world-famous. Azerbaijan meets $80 \%$ of world caviar production and seeks new markets. Salyan city, myrtle, catfish and canned food industry has developed (EIU Azerbaijan Country Report April 2000).

In 1999, 11.6 trillion Manat worth of industrial products was produced in industrial sector. Energy, petrochemical plants and private sector facilities had a great impact in the 3.5\% growth compared to the previous year. In 2000, 25.4\% of GNP fell to the share of industrial sector. A crop of 15,949.8 billion Manats ( $\$ 3564.8$ thousand) was produced. Production increased by $6.9 \%$ compared to 1999 production. $44.5 \%$ of the production belongs to the mining industry, $40.9 \%$ to the manufacturing industry and $14.6 \%$ to the electricity, gas and gas and water supply. Wine production is the most important production area in the food industry. In light industry, textiles, carpets, leather products, toys, furniture and bicycles are the main production lines. In heavy industry, intermediate goods and semi-finished products are generally produced. The oil industry forms the basis of heavy industry (Abbasli, 2001).

The oil, natural gas and by-products industry is highly developed. In addition, due to the production of metallic minerals (copper, zinc, lead, aluminum, iron) and raw material sources, the subsidiary industry has also developed. In Sumgait, there is iron and steel, non-ferrous metals processing industry and chemical industry; In Baku, Ganja and Mingechevir there is petroleum and natural gas industry and a subsidiary industry, electricity, machinery and equipment manufacturing industry. In the industrial sector, production capacity is higher than domestic demand in many areas but since the technology is not renewed, many factories are producing below the theoretical capacity. Major cuts in relations with CIS countries, difficulties in conducting inter-bank transactions, increase in raw material prices, inability to export manufactured goods, supply of sufficient amount of raw materials and auxiliary materials and materials, inability to use the funds allocated for production efficiently, inadequacy of financing resources, foreign exchange bottleneck and the fact that privatization does not reach a sufficient level are the main reasons for the decline in production (TIKA Publishers).

Azerbaijan is rich in underground resources. The main sources are; lead, zinc, copper, iron ore, barite, alunite, cobalt, arsenic, marble, limestone cyanide, mineral salt and rock salt. There are also precious metals like gold and silver (ALEKSANDROV, S. K.; Stranı Mira (Dünya Devletleri), Rus Politik-Edebiyat Politizdat Yayinları, Moskova, SSCB, 1989, s. 232).

Azerbaijan has 3 highway links to open seas. These are; the roads to the Black Sea via Georgia, to the Black Sea via Russia and to the Persian Gulf via Iran. The total length of Azerbaijan's roads is $24,900 \mathrm{~km}$ and these roads need maintenance. The total length of the railways is $2120 \mathrm{~km}$, and electrification has been made in $1278 \mathrm{~km}$. However, trains and railways need to be renovated and repaired. Direct and regular sea voyages are carried out between the coastal states of Azerbaijan and the Caspian Sea. The biggest port of the country is Baku Port. Baku Port needs maintenance and repair. There are flights from Baku Bine Air- 
port to former Soviet Republics and many other countries in the world. Turkish Airlines has regular flights from Istanbul to Baku and Azerbaijan Airlines from Baku to Ankara and Istanbul. The telecommunication infrastructure in the country is not sufficiently developed. The number of phones per hundred people is 8.8 (Bunyadov, 1989).

Azerbaijan's biggest underground wealth is oil. Oil and natural gas production rank first in terms of other underground resources. Oil entered into economic life with the 19th century. Gas production increases more slowly and oil production is increasing after independence. In 1999, 13.8 million tons of oil were produced (276,800 barrels/day), a large part of this amount (89\% of production) came from offshore areas. In January-May 2000 period, oil production increased by $7.1 \%$ to $5.93 \%$ million tons. In this period, gas production amounted to 2.4 billion cubic meters and decreased by $2.2 \%$ annually. The State Oil Company (SOCAR) operates mainly in coastal areas, while offshore areas are operated by consortiums led by Azerbaijan International Operating Company (AIOC). AIOC started oil production in late 1997. The share of production from offshore areas operated by AIOC is increasing. The economy depends on AIOC for a large part of its foreign investments; AIOC corresponds to US \$341 million of US \$510 million of foreign direct investments in 1999. Between December 1999 and May 2000, the National Oil Fund, where the state's income from AIOC was paid, earned US $\$ 75$ million (1.9\% of GDP).

Oil production was 14 million tons in 2000 and 14.9 million tons in 2001. The output of refined petroleum products continues to increase as refineries are involved the more in local oil production. The delated payment of the markets for the products related to the sales to the CIS or Iran is a problem. In the first five months of 2000, 65,000 tons of diesel fuel, worth US $\$ 12.9$ million, was sold to Ukraine, but only USD 4.6 million was paid. The transfer of 435,000 tons of diesel, which had to be sent in 2000 , was suspended until the remaining US $\$ 8.3$ million was paid. There is a decrease in diesel sales to Iran, because of the low price and high transportation costs given by Iran (Ismayilov, 1992).

Azerbaijan needs to allow the development of the oil sector through the construction of medium and long-term commercially viable oil export pipelines. There are two oil export pipelines from Baku to the port of Novorissiysk in the Black Sea and to the port of Supsa in Baku from Georgia. These two pipelines have similar capacities and can deliver a total of approximately 230,000 v/g. (ALLAHVERDİYEV, Nizameddin, GÖYÇAYLI, Şövqi; Azerbaycan Respublikasinin İqtisadi ve Sosial Coğrafiyası (Azerbaycan Cumhuriyetinin İktisadi ve Sosyal Coğrafyası), Azerbaycan Öyretmen Neşriyyatı Yayınları, Bakü, Azerbaycan, 1996, s. 97).

The Azerbaijani and Georgian Parliaments approved the legal framework for the construction of a pipeline from Baku to the Turkish port of Ceyhan in the months of May and June. This framework consists of the Istanbul Agreement signed on 18 November, 1999 by Azerbaijan, Georgia and Turkey, the Istanbul Declaration signed by Azerbaijan, Georgia, Kazakhstan, Turkey and the United 
States on 18 November, 1999 and the Protocol signed on 5 May, 2000 amending the Istanbul agreement. The length of the pipeline will be $1730 \mathrm{~km}$ and the oil spill rate will be 50 million tons (TÜSİAB Publishers) (Gumilev, 1990).

The construction sector is a stimulus sector for foreign investments due to the fact that materials and raw materials of the construction industry are abundant and cheap and there is a supply gap. The richest places in terms of building materials are Nakhichevan Mukhtar Republic, Dalyar, Khankendi, Masalli, Imishli, Ganja and Baku. The share of the construction sector in GDP was 8.1\% in 1990, $3.7 \%$ in $1995,9.3 \%$ in $1996,11.7 \%$ in $1997,10.5 \%$ in 1998 and $9.4 \%$ in 1999 and $4.4 \%$ in 2000 . Turkish companies play an important role among the companies operating in this sector. On August 7, 1992, "Law on the Central Bank" and "Law on the Operations of Banks and Banks' Operations" have been put into effect. It is aimed to establish a two-level banking system; the first level is the Central Bank; the second level is the other banks. The Central Bank of the Republic of Turkey has the authority to determine, audit and control policies in the money and banking sector (Allahverdiyev \& Goycayli, 1996).

\section{Discussions}

Banking law covers all banking transactions in the modern sense, but the targets cannot be realized due to the fact that the economy has not passed to the free market system and the banking system has not been established in the modern sense. As of 01.01.2000, the required minimum capital of the banks was increased to USD 2.000.000 in line with the policy of consolidating the banking system. The licenses of the banks which cannot reach this limit are canceled and the number of private banks is decreasing. As a result of the minimum capital application, the number of banks decreased by $2 / 3$ while there were more than 200 banks present in 1995 . From 75 banks in the country; 11 banks are with foreign capital or foreign capital participation; 4 banks are with state capital and 60 banks are with commercial and domestic partners. The most important one of the banks and the biggest so far as the transaction volume is concerned is Beynelhalk Bank. Foreign banks can be established with $100 \%$ foreign capital or can be established as a joint enterprise, branch or representative office. The Banks Act stipulates that the total capital of foreign banks cannot be more than $30 \%$ of the total capital of the banks in the system (Gumilev, 1991).

The banks with Turkish capital are Azer-Türk Bank (Ziraat Bank partnership), Koçbank, Royal bank and CIB bank. There are 62 insurance companies in the country. 16 of these insurance companies have banks as partners and there are 4 joint insurance companies. The minimum capital for insurance companies is 200 million Manats, i.e. approximately $\$ 50,000$. Most insurance companies are small and medium-sized companies. Insurance companies with Turkish capital are; Günay Anadolu Insurance, Başak-İnam Insurance and CI Insurance companies (Minorsky, 1953).

Inflation was pulled down from the figures in 1997, and prices declined in 1998, and despite the mini-devaluation in June 1999, domestic demand re- 
mained low, and so continued in 1999. Annual inflation in 1999 was " $-8.5 \%$ (deflation). The Central Bank (ANB) allowed inflation to increase slightly against the anti-inflationary guarantees in the years 2000-2001. Inflation increased from 0.9\% in January-May 1999 to 1.5\% between January and May 2000. The 2000-year inflation rate was 2.2, after a slight decline in inflation in 2001, a slight increase was observed in 2002 and was realized as $2.6 \%$.

After the devaluation in 1999 and the "dirty fluctuation" involving an intervention to remedy the depreciation of the value of Manat, market mechanisms targeting exchange rate adjustment was introduced. In the January-May 2000 period, Manat lost only $1.5 \%$ against the US Dollar. Manat has really appreciated against the currencies of the neighboring countries, since these countries have higher inflation rates. In the years 2000-2001, Manat depreciated against the US Dollar. The balance was achieved in 2002 and 2003. The trade gap in 1999 was the lowest value in five years. While the increased oil and refined product sales provided higher export gains, the devaluation of Manat helped to cut import costs as it slowed down investments in the oil sector. The trade balance of the foreign oil consortiums of Azerbaijan had a surplus due to the increased export and import of fewer capital goods for the petroleum sector. Final figures for 1999 confirm the tendency to move away from trade with the former Soviet Union and to shift to robust money markets. While the share of CIS in total trade was $27.7 \%$ in 1998 , this value was $22.6 \%$ in $1999,13.5 \%$ in 2000 and $7.4 \%$ in the first six months of 2001.

On the import side, the decline in imports from CIS countries and Russia was slower. With cheap rubles, Russia increased its share in Azerbaijan market in 1999 and increased its share in Azerbaijan imports from 18\% in 1998 to 21.9\% in 1999. Imports from other CIS countries, such as Ukraine, declined. Imports from Turkey, fell from $20.4 \%$ in the total value in 1998 to $13.8 \%$ in 1999 and to $6.0 \%$ in 2000. In order to strengthen trade in Azerbaijan, efforts are underway to increase production in the oil sector, to revitalize trade between CIS countries and to create new markets. In this context, two and multilateral agreements are signed (Aliyarov \& Mahmudov, 1989).

Azerbaijan's large trade and current account deficits are taken under controlled by increases in oil prices. The price of crude oil increased more than double between the first three months of 1999 and the first six months of 2000, and the oil export volume almost doubled during the same period. Although the Azerbaijan International Operating Company (AIOC) the country is not a major petroleum producer and exporter, exports are rapidly increasing due to the investment made by this company. By the end of 2000, Azerbaijan's foreign trade volume was realized as 2917.0 million USD. 17,744.9 million dollars (59.8\%) of this figure was exports and 1.172.1 million dollars (40.2\%) was imports. Foreign trade had a surplus of $\$ 572.8$ million. The number of countries with which commercial relations are established worldwide is $122.20 .9 \%$ of foreign trade was made with CIS and $79.1 \%$ with other 
countries (Hartill, 1990).

In the first 11 months of 2001, Azerbaijan's foreign trade balance has been 706.15 million USD. According to the State Statistics Committee, Azerbaijan's foreign trade volume was $\$ 3.31$ billion in January-October 2001. During the period, Azerbaijan established commercial relationship with 120 countries. During the first 11 months period, exports amounted to USD 2.01 billion and imports amounted to USD 1.3 billion. In the balance of payments, total exports in 1999. From the oil sector, export revenues of US $\$ 383.3$ million were provided, representing $37.4 \%$ of total export earnings and an increase of $189.3 \%$. The total exports of refined products increased by $189.5 \%$ annually and amounted to 21.7 million USD ( $8 \%$ of GDP). The economy other than oil continued to make lower exports. Cotton sales dropped from US $\$ 47.2$ million in 1998 (1.2\% of GDP) to US $\$ 21.7$ million in 1999 ( $0.5 \%$ of GDP), the lowest level after independence. Exports of machinery and equipment decreased by $15.6 \%$ in 1999 to US $\$ 34.7$ million in 1998, while it was amounting to US $\$ 41.1$ million in 1998. Azerbaijan's industry sector is not competitive, which leads to a decrease in exports while the imports of capital goods continue to increase.

In 2000, total exports amounted to USD 17,744.9 million. The volume of exports increased by $53.2 \%, 13.5 \%$ of this amount was with CIS and $86.5 \%$ with other countries. Petroleum and petroleum products are the most important in exports with 1484.9 million Dollars. $\$ 56.5$ million of foodstuff, $\$ 40.8$ million of textile products, $\$ 36.2$ million of chemical products, $\$ 34.8$ million of transportation vehicles and $\$ 32$ million of metal and metal products were exported (Gumilev, 1991).

Import costs were taken under control in 1999, but still high by world standards. Total imports in 1999 were US $\$ 1.43$ billion (35.8\% of GDP), decreasing by $16.9 \%$ from US $\$ 1.72$ billion in 1998 ( $41.9 \%$ of GDP). The slowdown in foreign direct investment (FDI) inflows caused the oil sector imports to decrease from US $\$ 355.7$ million in 1998 to US $\$ 194.9$ in 1999. Imports of other capital goods, especially imports of machinery and equipment, increased by $34.1 \%$ to US $\$ 458.8$ million in 1999 from US $\$ 342.2$ million in 1998 . In 1999 , food imports increased by $21.3 \%$ and increased from US $\$ 171.1$ million in 1998 to US $\$ 207.5$ million in 1999. Imports of metals other than chemicals and non-ferrous metals decreased (Aktukun, 1995).

Except for equipment and machinery, the largest single import item is the balance of payments adjustment made for imports that Azerbaijan customs statistics do not record. These imports are personal imports that are not declared by either illegal goods or cross-border shopping. In 1999 the cost of such imports to Azerbaijan amounted to USD 399.9 million (10\% of GDP). In 2000, total imports amounted to USD 1172.1 million. The volume of imports increased by $13.1 \%, 32 \%$ of this was with CIS countries ( $15.4 \%$ increase) and $68 \%$ with the other countries $(12.1 \%$ increase). Imports from Turkey have fallen by $11 \%$ in 2000 (Aras, 2003). 


\section{Result}

As explained in detail in this paper, after gaining its independence, Azerbaijan attempted to solve its own political and economic problems with the realization of projects related to the exploitation of these resources. The basic policy of the state is the diversification of transport routes to export its own energy resources to the world markets. The prosperous accomplishment of the Baku-Tbilisi-Ceyhan pipeline is a chief triumph in Azerbaijan's foreign policy. Certainly, in the mid-1990s, limited specialists assumed this pipeline would ever be built. As late as 2000, western, Russian, and Iranian analysts similarly could still be caught on record disputing that the probabilities of the pipeline being constructed were close to zero. In spite of the terrible projections, BTC was constructed to a noteworthy range because of an often-neglected aspect: it was the premeditated decision of the Azerbaijani administration to export its energy possessions over a western pipeline. This, in association with the Turkish straits matter, resilient U.S. government backing, and the lack of supplementary routes with both economic and political practicality, guaranteed that BTC arose as the only achievable opportunity for the export of Azerbaijani major oil. The fulfillment of the BTC pipeline carries main consequences for the expansion and solidification of Azerbaijan's statehood and independence, as well as for its relations with the Euro-Atlantic community. First of all, BTC safeguards that Azerbaijan's main economic possessions are not in the hands of regional powers that would be leaning to use this strength to effect or control Azerbaijan's foreign and domestic matters. But beyond this, BTC will help Azerbaijan to appear as a player on the global stage. As a fresh important non-OPEC source of oil, Azerbaijan will become a significant contributor to Europe's energy security, a anxiously needed asset given Russia's supremacy in the European energy market. Internally, the revenue generated by oil exported through BTC establishes a great occasion for Azerbaijan to find a short-cut in its economic conversion and in the building of a modern, prosperous and expanded economy. In political terms, BTC will be of huge implication for Azerbaijan's regional situation. Positioned in a strategic location and encircled by great powers, Azerbaijan's small population and size would incline to doom it to the character of an insignificant power under the effect of larger countries. Certainly, most countries in the Caucasus and Central Asia have often discovered themselves either under the overriding impact of one larger power, or strained to play off regional powers against one another to enlarge their own independence and liberty of action. This application spends considerable energies and hinders the growth and enactment of long-term strategic foreign policy aims. Furthermore, it makes the country reliant on the changes in strategy and attention of one or several regional powers. Undeniably, Armenia is severely reliant on sustained Russian assurance, just as Georgia depends on America's attention. Thanks to its energy assets, Azerbaijan stands a chance to accomplish its leadership's long-standing target to arise, as a regional player. This in no sense means Azerbaijan will develop to be a regional power; what it 
does mean is that Azerbaijan can build its country and security on a more equivalent foundation with its neighbors, as well as regional and large powers. This achievement, which Azerbaijan shares only with Kazakhstan and Uzbekistan in the wider region, would have been impossible without BTC. Of course, BTC is not a solution for as an answer to all of Azerbaijan's very actual encounters. Definitely, its outcome on the country's political expansion is uncertain, as it poses both an chance for political reforms and carries concurrent jeopardies for a slowdown of reforms. Similarly, BTC might considerably reinforce Azerbaijan's negotiating place concerning Armenia, and thus assist it to realize a negotiated resolution; but it might also surge the jeopardy of reintroduced aggressions. Finally, BTC delivers huge prospects for Azerbaijan's growth in political, economic, as well as strategic terms. The degree to which the plentiful prospects that are tied to BTC will be accomplished will be contingent on the administration's capability to exploit these prospects and opportunities (Bunyadov, 1989).

\section{Conflicts of Interest}

The authors declare no conflicts of interest regarding the publication of this paper.

\section{References}

Abbasli, N. (2001). The Liberation Struggle in Azerbaijan. Istanbul: Balina Publications.

Aktukun, I. (1995). How the CIS Was Reached from the USSR. Determinations for a Marxist Analysis. Istanbul: Sorun Publications.

Aliyarov, S., \& Mahmudov, Y. (1989). Sources for the History of Azerbaijan History. Baku: Azerbaijan University Publications.

Allahverdiyev, N., \& Goycayli, S. (1996). Economic and Political Geography of Azerbaijan Republic. Baku: Azerbaijan Teacher Publications.

Aras, O. (1998). Our Azerbaijan Case. Istanbul: Hamle Publications.

Aras, T. R. (2003). Foreign Politics of Ataturk. Istanbul: Kaynak Publications.

Asanishvili, G. (2003). 1st International Silk Road Symposium on Media News; "24 SAATI", 26, Scientific and Political Aspects of the "Great Silk Road".

Bunyadov, Z. (1989). Azerbaijan in VII-IX Centuries. Baku: Azerbaijan State Publications.

Gumilev, L. N. (1990). Ethnic Geography Conception in Historical Process. Sankt Peterburg: Nauka Publications.

Gumilev, L. N. (1991). Analysis of the Thousand Year Process around the Caspian Sea. Baku: Azerbaijan State Publications.

Hartill, L. R. (1990). Azerbaijan Events of 1918-1922 in the Memoirs of an Armenian (Translated by Sipahi Cataltepe). Istanbul: Kastas Publications.

Ismayilov, M. (1992). Azerbaijan History. Baku: Azerbaijan State Publications.

Makas, Z. A. (1990). Azerbaijan History and Cultural Geography. Ankara: Kok Social and Strategic Researches, Kok Publications.

Minorsky, V. (1953). Studies in Caucasian History. With a Map. London: Taylor's Foreign Press. 
E. H. Mikail et al.

Ulku, I. (1996). From the Red Star to Crescent: Stormy Life of Haydar Aliyev (2nd ed.). Istanbul: Kamer Publications.

Ulku, I. (2000). Azerbaijan, after Independence. Istanbul: Dogan Books Publications. 